Endocrinol. Japon. 1985, 32 (2), 295-303

\title{
Human Transcortin Synthesis by a Cell-Free Translation of Hepatic mRNA
}

\author{
Kaori SUEDa, Hisao SEO and Nobuo Matsui \\ The Research Institute of Environmental Medicine \\ Nagoya University, Furo-cho, Chikusa-ku, Nagoya 464
}

\begin{abstract}
To evaluate the site of synthesis and to characterize the translated transcortin, poly (A)-containing RNA (mRNA) from human liver was translated in a cell-free system derived from rabbit reticulocyte lysate. The in vitro synthesized product was identified as transcortin by immuno-precipitation with its specific antiserum. This translated transcortin could be displaced from the antibody by unlabeled purified transcortin obtained from plasma. Furthermore, when the translation mixture was applied to a cortisol-Sepharose column, the translated transcortin was bound to the matrix in a specific manner, indicating that this product binds to cortisol. The molecular weight of the translated transcortin was estimated to be 45,700 by its mobility in sodium dodesyl sulfate polyacrylamide gel electrophoresis, while that of plasma transcortin was 53,800 . The difference in molecular weight between the translated transcortin and plasma transcortin was probably due to the presence of presequence (signal peptide) in addition to the absence of carbohydrate moiety in the former.

In conclusion, human liver mRNA directed the synthesis of transcortin, and the translated transcortin binds to cortisol in spite of the absence of carbohydrate moiety.
\end{abstract}

Transcortin is a binding protein specific for corticosteroid in plasma (Daughaday, 1958; Slaunwhite and Sandberg, 1959). Since protein-bound corticosteroids are inactive physiologically (Matsui and Plager. 1966; Westphal, 1971), the variation in transcortin concentration is of great importance in the modulation of glucocorticoid activity (Matsui et al., 1979; Yamamoto et al., 1983).

The site of synthesis of transcortin has been supposed to be the liver (Gala and Westphal, 1966; Doe et al., 1964), but no definite proof of this had been obtained.

Received December 14, 1984
Recently, Weiser et al. (1979) demonstrated in rat that liver slice, incubated in vitro, synthesized a corticosteroid binding protein which might be transcortin. In addition, hepatic synthesis of transcortin was confirmed by in vitro translation of liver mRNA obtained from guinia pigs and rats (PerrotApplanat and Milgrom, 1979; Wolf et al., 1981). However, no study in human liver has been published.

Muldoon and Westphal (1976) reported that enzymatic removal of sialic acid from human transcortin did not affect its cortisolbinding affinity. On the other hand, Murata et al. (1984) reported that translated thy- 
roxine binding globulin (TBG) did not have binding activity, suggesting the importance of carbohydrate moiety in the tertiary structure of the biologically active TBG.

In this study, human liver poly (A)-containing RNA was translated in a cell-free system to confirm whether human transcortin is also synthesized in the liver. The presence of transcortin in the translation products was identified by immuno-precipitation using specific antiserum to human transcortin. The size and the cortisol-binding activity of the translated transcortin were also studied.

\section{Materials and Methods}

\section{Materials}

$\mathrm{L}-\left[3,4,5-{ }^{3} \mathrm{H}(\mathrm{N})\right]$-leucine $(158.0 \mathrm{Ci} / \mathrm{mmol})$ and $\left[1,2,6,7-{ }^{3} \mathrm{H}(\mathrm{N})\right]$-cortisol $\quad(91.0 \mathrm{Ci} / \mathrm{mmol})$, EN${ }^{3} \mathrm{HANCE}$ were purchased from New England Nuclear Corp. (Boston, Mass., U.S.A.). NCS was from Amersham (Buckinghamshire, England). Poly(U)-Sepharose was from Pharmacia Fine Chemicals (Uppsala, Sweden). Micrococcal nuclease was from Boehringer Mannheim (Mannheim, West Germany), creatine phosphate kinase was from Signa Chemical Company (ST. Louis, U.S.A.). Molecular weight standards for sodium dodesyl sulfate (SDS)/ polyacrylamide gel electrophoresis were from Bio-Rad Laboratories (Richimond, Calif., U.S.A.). Cortisol-Sepharose (21-deoxy-21-( $\omega$-aminohexyl) aminocortisol-agarose) was prepared according to the method of Chan et al. (1977). Ultrogel AcA 44 was purchased from LKB (Bromma, Sweden). Antihuman transcortin antibody was raised in a rabbit by immunization with purified transcortin (Sueda et al., 1983). In order to remove nonspecific antibodies, the antiserum was incubated with pooled human serum $(v / v ; 1: 1)$ at $37^{\circ} \mathrm{C}$ for $30 \mathrm{~min}$ and centrifuged at $3,000 \times \mathrm{g}$ for $15 \mathrm{~min}$ and the supernatant was used as a specific antitranscortin antibody. Anti-human albumin antiserum (rabbit), and rabbit gamma globulin (Fraction II) were obtained from Miles Laboratories, Inc. (Eckerhalt, Indiana, U.S.A.). Anti-rabbit gamma-globulin antibody was raised in a goat. Human transcortin was isolated from pooled se- rum and purified as described previously (Sueda et al., 1983).

\section{Extraction of RNA}

Human liver was obtained from an autopsy of a 29-year-old male patient who had died of lung cancer. No metastatic lesion was observed macroscopically. The liver was immediately placed in ice, freed from connective tissue, then chopped into small pieces, frozen in liquid $\mathrm{N}_{2}$ and stored at $-80^{\circ} \mathrm{C}$ until use. Five grams of the liver pieces were pulverized and homogenized in $10 \mathrm{vol}$ of $200 \mathrm{mM}$ Tris- $\mathrm{HCl}(\mathrm{pH} 8.6), 50 \mathrm{mM}$ $\mathrm{KCl}, 25 \mathrm{mM} \mathrm{MgCl}, 200 \mathrm{mM}$ sucrose, $0.5 \mathrm{mg} / \mathrm{ml}$ heparine and $0.1 \%$ Triton X-100. After centrifugation at $600 \times \mathrm{g}$ for $10 \mathrm{~min}$, the supernatant was added to $4 \mathrm{vol}$ of $10 \mathrm{mM}$ Tris- $\mathrm{HCl}(\mathrm{pH} \mathrm{8.6)}$, $100 \mathrm{mM} \mathrm{NaCl}, 5 \mathrm{mM}$ EDTA and $1.2 \%$ SDS and the mixture was extracted with phenol-chloroform (Seo et al., 1977). The ethanol-precipitated RNA was successively washed with $2 \mathrm{M} \mathrm{LiCl}$ and $66 \%$ ethanol in $100 \mathrm{mM} \mathrm{NaCl}$. The poly (A)containing RNA (mRNA) was purified by poly (U)-Sepharose chromatography (Vassart et al., 1975). The mRNA thus obtained was dissolved in sterile water at a concentration of $1 \mathrm{mg} / \mathrm{ml}$ and stored at $-20^{\circ} \mathrm{C}$

Globin mRNA was also prepared from rabbit reticulocyte lysate (Sala-Trepat et al., 1978).

\section{Cell-free translation of liver $m R N A$ by re- ticulocyte lysate}

The rabbit reticulocyte lysate was prepared according to the method of Palmiter et al. (1973), and treated with micrococcal nuclease to reduce endogenous mRNA activity (Pelham and Jackson, 1976). The protein synthesizing system in a final volume of $0.1 \mathrm{ml}$ contained $80 \mu \mathrm{l}$ of treated reticulocyte lysate, $10 \mathrm{mM}$ creatine phosphate, $5 \mu \mathrm{g}$ of creatine phosphate kinase, $15 \mu \mathrm{M}$ of each 19 L-amino acids required for protein synthesis (except leucine), $10 \mu \mathrm{Ci}$ of ${ }^{3} \mathrm{H}$-leucine, $100 \mathrm{mM} \mathrm{KCl}$ and 0.1 to $0.5 \mu \mathrm{g}$ of mRNA. Incubation was performed at $30^{\circ} \mathrm{C}$ for $1 \mathrm{~h}$, and the reaction was stopped by cooling to $0^{\circ} \mathrm{C}$ and adding $0.1 \mathrm{ml}$ of the solution containing $2 \%$ deoxycholic acid, $2 \%$ Triton X-100 and $0.2 \%$ unlabeled leucine.

\section{Assay of $m R N A$ activity}

Activity of mRNA was estimated by the amount of newly synthesized product. Newly synthesized total protein was precipitated with trichloroacetic acid (TCA) as reported by Shimke 
et al. (1974). Translated transcortin and albunin were immuno-precipitated from the translation mixture using a double antibody technique (Pasteels et al., 1971). The TCA precipitate and immuno-precipitates were digested in $1 \mathrm{ml}$ of $\mathrm{NCS}$ at $50^{\circ} \mathrm{C}$ and radioactivity was measured.

\section{SDS-polyacrylamide gel electrophoresis of translation products}

The purified immuno-precipitate from the translation mixture was dissolved in $50 \mu \mathrm{l}$ sample buffer (10 mM Tris-HCl buffer $\mathrm{pH} 6.8,2 \%$ SDS, $10 \%$ glycerol $(\mathrm{v} / \mathrm{v})$ and $1 \%$ 2-mercaptoethanol), heated at $80^{\circ} \mathrm{C}$ for $5 \mathrm{~min}$ and analyzed on $10 \%$ SDS-polyacrylamide gel electrophoresis (Laemli, 1970). The gel was treated with $\mathrm{EN}^{3} \mathrm{HANCE}$ and its radioactivity was assessed by fluorography (Laskey and Mills, 1975) using Kodak X Omat AR film. Molecular weight standards were electrophoresed at the same time and were stained with Commassie brilliant blue $\mathrm{R}$.

6. Binding of translated transcortin to cortisolSepharose

The translation mixture $(0.4 \mathrm{ml})$ was incubated with cortisol-Sepharose $(0.1 \mathrm{ml}$ of packed gel) at $4^{\circ} \mathrm{C}$, and the mixture was transferred into a column $(0.5 \times 1.0 \mathrm{~cm})$. Fractionation was per- formed by a modification of the procedure of Rosner and Bradlow (1971). Pass-through fraction was collected (fraction $\mathrm{I}$ ), and the column was washed with $1 \mathrm{ml}$ of $0.05 \mathrm{M}$ phosphate bufier, $\mathrm{pH} 7.0$, containing $0.1 \mathrm{M} \mathrm{NaCl}$ (fraction II). Then, the column was eluted with $1 \mathrm{ml}$ of $0.01 \mathrm{M}$ phosphate buffer, pH 7.0, containing $200 \mathrm{rg} / \mathrm{ml}$ of cortisol (fraction III), and finally with $1 \mathrm{ml}$ of $0.05 \mathrm{M}$ phosphate bufter pH 7.0, containing 200 $\mu \mathrm{g} / \mathrm{ml}$ of cortisol and $0.1 \mathrm{M} \mathrm{NaCl}$ (fraction IV). Radioactivities of TCA precipitate and of the immuno-precipitate by anti-transcortin antiserum were measured in each fraction.

\section{Results}

1. Specificity of anti-human transcortin antiserum

In order to examine the specificity of the antiserum, immuno-electrophoresis was carried out. A single precipitin line was formed when the anti-transcortin antiserum was incubated with either purified plasma transcortin or human serum (Fig. 1-A). Furthermore, when such immuno-electro-

\section{A. staining}

a

b

\section{B. autoradiography}

C

d

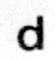

Fig. 1. Immuno-electrophoresis of human serum by anti-transcortin antiserum

Pooled serum (a) and purified transcortin (b) were mixed with a trace amount of ${ }^{3} \mathrm{H}$ cortisol and electrophoresed in Tris-glycine buffer, $\mathrm{pH} 8.6$ for 90 min at 150 volt. Then the wells were filled with antiwhole serum antiserum (c) and anti-transcortin antiserum (d). After diffusion for $24 \mathrm{~h}$ to permit formation of precipitin arcs, the gel was washed, dried and autoradiographed (B). The gel was then stained with Commassie Brilliant Blue $R(A)$. 
phoresis was carried out in the presence of ${ }^{3} \mathrm{H}$-cortisol, radioactivity was detected only at the precipitin line (Fig. 1-B). The specific interaction between antibody and purified transcortin was also observed in the Ouchterlony double diffusion test (data not shown).

2. In vitro translation of human liver $m R N A$ After translation of liver mRNA, the newly synthesized product was analyzed by TCA precipitation and by immuno-precipitation with anti-transcortin antiserum. The results are shown in Table 1 . Radioactivity of ${ }^{3} \mathrm{H}$-leucine in TCA precipitate was 229,393 dpm (A), while that in immuno-precipitate was $8,926 \mathrm{dpm}$ (B). When purified plasma transcortin $(30 \mu \mathrm{g})$ was added to the translation mixture, radioactivity of ${ }^{3} \mathrm{H}$-leucine in the immuno-precipitate (B) clearly decreased from 8,926 to $6,255 \mathrm{dpm}$. The radioactivity in the immuno-precipitate obtained in the presence of $30 \mu \mathrm{g}$ transcortin appears to represent the non-specific absorption, because calibration of the antibody displacement revealed that $30 \mu \mathrm{g}$ of cold transcortin completely displaced the radioactive transcortin from the antibody in the present assay system. Thus, the specific counts for transcortin (C) in the absence and presence of $3 \mu \mathrm{g}$ of cold transcortin

Table 1. TCA precipitable and immunoprecipitable radioactivity in the translation product of liver mRNA and influence of the addition of plasma transcortin

\begin{tabular}{cccrr}
\hline $\begin{array}{c}\text { Plasma } \\
\text { trans- } \\
\text { cortin }\end{array}$ & $\begin{array}{c}\text { Radioactivity } \\
\text { in } \\
\text { TCA- } \\
\text { precipitate }\end{array}$ & \multicolumn{2}{c}{$\begin{array}{c}\text { Radioactivity } \\
\text { in } \\
\text { immuno- } \\
\text { precipitate }\end{array}$} & $\begin{array}{c}\text { Trans- } \\
\text { cortin \% }\end{array}$ \\
added & (A) & (B) $/(\mathrm{A})$ & (C) & $\begin{array}{r}\text { (C) } \\
\times 100\end{array}$ \\
\hline$\mu \mathrm{g}$ & $\mathrm{dpm}$ & $\mathrm{dpm}$ & $\mathrm{dpm}$ & $\%$ \\
0 & 229,393 & 8,926 & 2,671 & 1.2 \\
3 & 229,393 & 8,354 & 2,099 & 0.9 \\
30 & 229,393 & 6,255 & 0 & 0 \\
\hline
\end{tabular}

(B) total immuno-precipitable count

(C) specific inmuno-precipitable count were 2,671 and $2,099 \mathrm{dpm}$, respectively. These represent $1.2 \%$ and $0.9 \%$ of TCA precipitable radioactivity. Although slight, consistent decreases in the specific counts for transcortin was obtained by adding 3 and $30 \mu \mathrm{g}$ of plasma transcortin.

In comparison, one of the most abundant mRNA in the human liver, namely albumin mRNA, was also studied. Radioactivity of immuno-precipitate specific for anti-albumin antiserum was $15-20 \%$ of TCA precipitable radioactivity (data not shown).

3. Analysis of the translated transcortin by SDS polyacrylamide gel electrophoresis

The translation product of liver mRNA was precipitated by anti-transcortin antiserum. The precipitate was applied on SDSpolyacrylamide gel electrophoresis. A single radioactive band was observed as shown in Fig. 2-A. No radioactive band was detected when normal rabbit serum was used instead of anti-transcortin antiserum. Again, no band was observed when translation was carried out either without liver mRNA or with globin mRNA. When the immunoprecipitate was electrophoresed with several molecular weight markers, the molecular weight of translated transcortin was estimated to be about $45,700 \pm 1,600$ (Mean士 $\mathrm{SD}, \mathrm{n}=3$ ). The molecular weight of plasma transcortin determined in the same system was estimated to be $53,800 \pm 1,000$ (data not shown).

The immuno-precipitate by anti-albumin antiserum presented a major band and several minor bands on SDS-polyacrylamide gel electrophoresis. The molelcular weight of the major one was $70,200 \pm 600$ (Fig. 2-B).

\section{Cortisol-binding activity of the translated transcortin}

Cortisol-binding activity of translated transcortin was examined by using cortisolSepharose. After translation product was incubated with cortisol-Sepharose, the mixture was transferred to a colum, from which 
four fractions were obtained. As shown on Table 2, radioactivity in TCA precipitate rapidly decreased as elution progressed. In the case of radioactivity of the immuno- precipitate with anti-transcortin antiserum, though it decreased as elution progressed, its percentages in TCA precipitable radioactivity markedly increased in fractions III

\section{A B}

$-200$
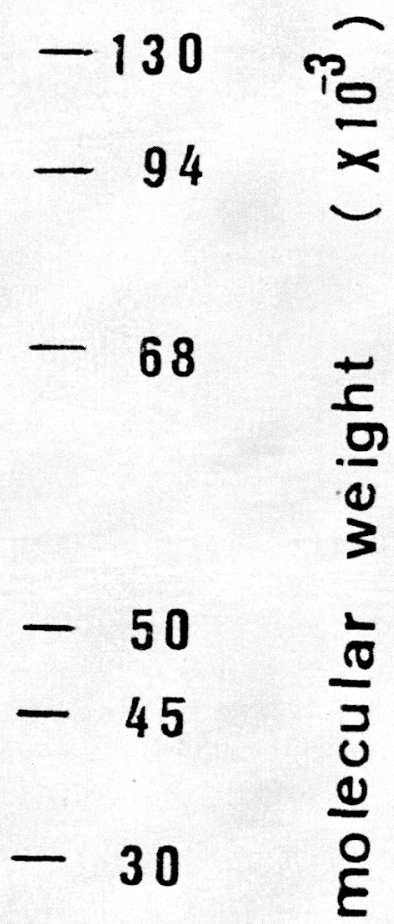

Fig. 2. Analysis of translated transcortin by SDS-polyacrylamide gel electrophoresisFluorography of "H-leucine

Translation product of human liver mRNA in the reticulocyte lysate was immunoprecipitated with specific antiserum and subjected to SDSpolyacrylamide gel electrophoresis (Laemli, 1970). Radioactivity was examined by fluorography (Laskey and Mills, 1975).

The molecular weight of the immuno-precipitate was compared with that of myosin (molecular weight ; 200,000), $\beta$-galactosidase $(130,000)$, phosphorylase B $(94,000)$, bovine serum albumin $(68,000)$, IgG heavy chain $(50,000)$, ovalbumin $(45,000)$ and carbonic anhydrase $(30,000)$.

$A$; the immuno-precipitate with anti-transcortin antiserum

$\mathrm{B}$; the immuno-precipitate with anti-albumin antiserum] 
Table 2. Binding of translated transcortin to cortisol-Sepharose

\begin{tabular}{lcrr}
\hline \hline $\begin{array}{c}\text { mRNA for } \\
\text { translation }\end{array}$ & $\begin{array}{c}\text { Radio- } \\
\text { activity } \\
\text { in TCA } \\
\text { precipitate } \\
\text { (A) }\end{array}$ & $\begin{array}{c}\text { Radio- } \\
\text { in } \begin{array}{c}\text { activity } \\
\text { immuno- } \\
\text { precipitate } \\
\text { (B) }\end{array}\end{array}$ & (B)/(A) $) \times 100$ \\
\hline & dpm & dpm & $\%$ \\
Human liver mRNA & & & \\
Fraction I & $1,384,590$ & 17,865 & 1.29 \\
Fraction II & 247,860 & 6,707 & 2.71 \\
Fraction III & 21,690 & 6,147 & 28.34 \\
Fraction IV & 5,350 & 1,815 & 33.93 \\
Globin mRNA & & & \\
Fraction I & $6,593,440$ & 6,066 & 0.09 \\
Fraction II & 717,520 & 334 & 0.04 \\
Fraction III & 90,080 & 98 & 0.10 \\
Fraction IV & 70,320 & 33 & 0.04 \\
\hline
\end{tabular}

and IV. Since these fractions were eluted by the cortisol containing buffer, antiserum precipitable radioactivity is considered to have been bound to cortisol-Sepharose in a competitive manner with cortisol.

To ascertain the specificity of the binding to cortisol-Sepharose, the translation mixture of globin mRNA was treated in the same manner. Despite the fact that TCA precipitable radioactivity of globin mRNA was 5 times more than that of liver mRNA, the radioactivity of the immunoprecipitate was less than that of liver mRNA in all fractions. The radioactivity in immunoprecipitate decreased in parallel with that in the TCA precipitate, the former was less than $0.1 \%$ of the latter in all fractions, and no increases in the percentage in fractions III and IV were observed.

\section{Discussion}

The poly (A)-containing RNA (mRNA) was purified from human liver obtained at autopsy and translated in a cell-free reticulocyte lysate system. The fidelity of the translation system was ascertained by albumin mRNA activity. Translation products of human liver mRNA contained a protein or proteins which were precipitated by antialbumin antiserum. The precipitate showed one major band and several minor bands on SDS-polyacrylamide gel electrophoresis. The molecular weight of the major product $(70,200 \pm 600)$ was concordant with that of pre-proalbumin reported previously in the rat (Strauss et al., 1977). It was not clear whether the minor bands might represent the materials precipitated by the contaminants in anti-albumin antiserum or the prematurely terminated peptides. In addition, albumin specific radioactivity represented $15-20 \%$ of TCA precipitable radioactivity, which is consistent with previous data in rats (Keller and Taylor, 1976; Peters and Peters, 1972).

Using this in vitro translation system, it was demonstrated that translation products of human liver mRNA contained a protein which was precipitated by anti-transcortin antiserum. The specificity of anti-transcortin antiserum was ascertained by Ouchterlony double diffusion test and immuno-electrophoresis (Fig. 1). The binding of translated product to the anti-transcortin antibody could be displaced by purified plasma transcortin (Table 2).

The molecular weight of translated transcortin was calculated to be 45,700 from its mobility on SDS-polyacrylamide gel electrophoresis, while that of plasma transcortin was 53,800 in the same condition. Since glycosylation of nascent protein does not occur in the cell free system used, the discrepancy in the molecular weight might partly be attributed to the lack of carbohydrate in translated transcortin. The molecular weight of the deglycosylated polypeptide of plasma transcortin was calculated to be 39,800 , assuming that the carbohydrate content of transcortin is $26.1 \%$ as reported by Muldoon and Westphal (1967). Therefore, translated transcortin seemed to be slightly larger than the deglycosylated transcortin. 
Recently a number of studies have demonstrated that the products of cell-free translation of secretory proteins are larger than native secreted forms and have signal sequences (15-30 amino acids residue extentions at $\mathrm{NH}_{2}$-terminal) (Lingappa and Blobel, 1980). Since transcortin is also a secretory protein and the molecular weight of the translated transcortin was larger than the assumed molecular weight of deglycosylated transcortin, it is probable that the translated transcortin is a precursor form having a signal peptide.

The steroid-binding activity of translated transcortin was examined using cortisolSepharose. The pass-through fraction and fraction eluted with a buffer without cortisol contained some radioactivity that was precipitated by anti-transcortin antiserum. The amount of this radioactivity comprises $1-3 \%$ of total TCA precipitable radioactivity. On the other hand, the percentage of immunoprecipitable radioactivity in TCA precipitable radioactivity reached approximately $30 \%$ in fractions eluated with cortisol containing buffer. Such specific binding for cortisolSepharose was not seen in the translation product of globin mRNA. These results indicate that the translated transcortin has cortisol-binding activity. Thus, the presence of the signal peptide and the absence of carbohydrate moiety does not interfere with the cortisol-binding activity of transcortin.

The presence of transcortin has been reported in kidney (Feldman et al., 1976), brain and pituitary (Koch et al., 1976: Dekloet and McEwen, 1976), muscle (Mayer et al., 1975), lung (Giannopoulos, 1976) and uterus (Milgrom and Baulien, 1970), in addition to the liver. It is not known whether these proteins are synthesized in situ or transported there by circulation. Hepatic synthesis of transcortin was confirmed by in vitro translation using liver mRNA obtained from guinea pigs and rats (PerrotApplanat and Milgrom, 1979; Wolf et al., 1981). From clinical observation showing that serum transcortin concentration was low in the patient with liver cirrhosis, transcortin has been suggested to be synthesized in human liver (Doe et al., 1964). However, no definite proof of this has been presented so far. The results of the present study strongly suggest that the human liver is the site of transcortin synthesis.

\section{Acknowledgements}

The authors wish to thank Dr. Y. Ariyoshi (Aichi-ken Cancer Center) for his fruitful discussion and collaboration.

This work was supported in part by the Naito Foundation Research Grand for 1981 and a Grant-in-Aid for Scientific Research (No. 58570997) from the Japanese Ministry of Education, Science and Culture.

\section{References}

Chan, D. W., M. Sharma and W. R. Slaunwhite Jr. (1977). The chemistry of human transcortin; Improved affinity matrices for the purification of transcortin. Arch. Biochem. Biophys. 182, 197-202.

Daniels-McQueen, S., D. McWilliams, S. Birken, R. Canfield, T. Landefeld and I. Boime (1978). Identification of mRNAs encoding the $\alpha$ and $\beta$ subunits of human choriogonadotropin. $J$. Biol. Chem. 253, 7109-7114.

Daughaday, W. H. (1958). Binding of corticosteroids by plasma protein. III. The binding of human plasma and plasma protein fractions. J. Clin. Invest. 37, 511-518.

Dekloet, E. R. and B. S. McEwen (1976). A putative glucocorticoid receptor and transcortinlike macromolecule in pituitary cytosol. Biochem. Biophys. Acta. 421, 115-123.

Doe, R. P., R. Fernandez and U. S. Seal (1964). Measurement of corticosteroid-binding globulin in man. J. Clin. Endocr. 24, 1029-1039.

Feldman, D., J. W. Funder and I. S. Edelman (1973). Evidence for a new class of corticosterone receptors in the rat kidney. Endocrinology 92, 1429-1441.

Gala, R. R. and U. Westphal (1966). Further studies on the corticosteroid-binding globulin in the rat; proposed endocrine control. Endo- 
crinology 76, 67-76.

Giannopoulos, G. (1976). A comparative study of receptors for natural and synthetic glucocorticoids in fetal rabbit lung. J. Steroid Biochem. 7, 553-559.

Keller, G. H. and J. M. Taylor (1976). Effect of hypophysectomy on the synthesis of rat liver albumin. J. Biol. Chem. 251, 3768-3773.

Koch, B., B. Luts-Bucher, B. Briand and C. Mialhe (1976). Heterogeniety of pituitary glucocorticoid binding: evidence for transcortin-like compound. Biochem. Biophys. Acta. 444, 497-507.

Laemmli, U. K. (1970). Cleavage of structural proteins during the assembly of the head of bacteriophage $T_{4}$. Nature 227, 680-685.

Laskey, R. A' and A. D. Mills (1975). Quantitative Film detection of ${ }^{3} \mathrm{H}$ and ${ }^{14} \mathrm{C}$ in polyacrylamide gel by fluorography. Eur. $J$. Biochem. 56, 335-341.

Lingappa, V. R. and G. Blobel (1980). Early events in the biosynthesis of secretory and membrane proteins: The signal hypothesis. Rec. Prog. Hormone Res. 36, 451-475.

Matsui, N. and J. E. Plager (1966). In vitro physiological activity of protein-bound and unbound cortisol. Endocrinology 78, 1159-1164.

Matsui, N., M. Yamamoto, H. Seo, M. Niinomi and Y. Ariyoshi (1979). Determination of serum cortisol frations by isocolloidosmolar equilibrium dialysis. Changes during pregnancy. Endocrinol. Japon. 26, 263-273.

Mayer, M., N. Kaiser, R. J. Milholland and F. Rosen (1975). Cortisol binding in rat skeletal musle. J. Biol. Chem. 250, 1207-1211.

Milgrom, E. and E. E. Baulien (1970). Progesterone in uterus and plasma. I. Binding in rat uterus $105,000 \mathrm{~g}$ supernatant. Endocrinology 86, 276-287.

Muldoon, T. G. and U. Westphal (1967). Steroidprotein interactions. XV. Isolation and characterization of corticosteroid-binding globulin from human plasma. J. Biol. Chem. 242, 5636-5643.

Murata, Y., S. Refetoff, G. Vassart and H. Seo (1984). Synthesis of bioactive tyroxine binding globulin (TBG) from human liver mRNA. Proc. VII Internatl. Congr. Endocrinol. 1215.

Palmiter, R. D. (1973). Rate of ovalbumin messenger ribonucleic acid synthesis in the oviduct of estrogen-primed chicks. J. Biol. Chem. 248, 8260-8270.

Pasteels, J. L., A. Danguy, M. Frerotte and F. Ectors (1971). Inhibition de la sécrétion de prolactine par l'ergocornine et la $2-\mathrm{Br}-\alpha-$ ergocryptine: action directe sur I' hypophyse en culture. Ann. Endocrinol. (Paris) 32, 188-192.

Pelham, H. R. B. and R. J. Jackson (1976). An efficient mRNA-dependent translation system from reticulocyte lysates. Eur. J. Biochem. 67, 247-256.

Perrot-Applanat, M. and E. Milgrom (1979). Messenger ribonucleic acid for corticosteroid-binding globulin. Translation and preliminary characterization. Biochemistry 18, 5732-5737.

Peters, J. Jr. and J. C. Peters (1972). The biosynthesis of rat serum albumin. VI Intracellular transport of albumin and rates of albumin and liver protein synthesis in vivo under various physiological conditions. J. Biol. Chem. 247, 3858-3868.

Rosner, W. and H. L. Bradlow (1971). Purification of corticosteroid-binding globulin from human plasma by affinity chromatography. $J$. Clin. Endocr. 32, 193-198.

Sala-Trepat, J., M. J. Savage and J. Bruner (1978). Isolation and characterization of poly (adenylic acid)-containing messenger ribonucleic acid from rat liver polysomes. Biochem. Biophys. Acta. 519, 173-193.

Seo, H., G. Vassart, H. Brocas and S. Lefetoff (1977). Triiodothyronine stimulates specifically growth hormone mRNA in rat pituitary tumor cells. Proc. Natl. Acad. Sci. U.S.A. 24, 20542058.

Shimke, R. T., R. E. Rhoads and G. S. Mcknight (1974). Assay of ovalbumin mRNA in reticulocyte lysate. in: Methods in Enzymology (K. Moldave and L. Grossman eds). Academic Press, New York, Vol. 30, 694-701.

Slaunwhite, W. R. and A. A. Sandberg (1959). Transcortin, a corticosteroid binding protein of plasma. J. Clin. Invest. 38, 384-391.

Strauss, A. W., C. A. Bennett, A. M. Donohue, J. A. Rodkey and A. W. Alberts (1977). Rat liver pre-proalbumin: complete amino acid sequence of the pre-piece. J. Biol. Chem. 252, 6846-6855.

Sueda, K., K. Ogawa and N. Matsui (1983). Radioimmunoassay of human transcortin. Endocrinol. Japon. 30, 737-745.

Vassart, G., H. Brocas, R. Lecocq and J. E. Dumont (1975). Thyroglobulin messenger RNA: Translation of a 33-S mRNA into a peptide immunologically related to thyroglobulin. Eur. J. Biochem. 55, 15-22.

Weiser, J. N., Y-S. Do and D. Feldman (1979). 
Synthesis and secretion of corticosteroid-binding globulin by rat liver. J. Clin. Invest. 63, 461-467.

Westphal, U. (1971). In : Steroid-protein interactions (A. S. Labhart, T. Mann and L. T. Samuels eds), Springer-Verlag, Berlin-Heiderberg-New York, 434-437.

Wolf, G., E. G. Armstrong and W. Rosner (1981).
Synthesis in vitro of corticosteroid-binding globulin from rat liver messenger ribonucleic acid. Endocrinology 108, 805-811.

Yamamoto, M., Y. Ariyoshi and N. Matsui (1983). The serum concentrations of unbound, transcortin bound and albumin bound cortisol in the patients with dysproteinemia. Endocrinol. Japon. 29, 639-646. 